\author{
Jason Blake* \\ University of Ljubljana, Slovenia
}

\title{
POSTNATIONAL WANDERINGS AND BECOMING CANADIAN (ABROAD)
}

\begin{abstract}
According to Prime Minister Justin Trudeau, Canada is "the first postnational state." Given that Canada has no clear mainstream, it is hard to disagree. Indeed, some three decades ago, scholar Linda Hutcheon argued that Canadians, given our widespread "split sense of identity," were primed for the postmodern. In this paper, I look at home, nation, and the bugbear of Canadian identity. My approach is autobiographical, though I do lean on authors Nancy Huston, Josip Novakovich, Rohinton Mistry, and Mark Anthony Jarman. My argument is this: leaving Canada helps crystallize concepts of what it can mean to be Canadian. Every day I am reminded of my "Canadianness" and of how I act out a type of Canadianness, not least because being outside Canada means I wrestle daily with a divided sense of self.
\end{abstract}

\section{Keywords}

Canadian identity, diaspora, postmodern, accent, split identity.

\section{Postnational Wanderings and Becoming Canadian (Abroad)}

THANK YOU, Madam Ambassador, friends, colleagues, and friends and colleagues. I have been to Belgrade only once - back in 2003. That was for an Embassy-sponsored conference entitled "Other Language: Otherness in Canadian Culture." It was one of the first Canadian Studies events I attended after

\footnotetext{
*JasonFrederick.Blake@ff.uni-lj.si
} 
moving to Europe in 2000. I met many fine people, and that is also why today I can say "friends and colleagues."

The title of my talk is "Postnational Wanderings and Becoming Canadian (Abroad)." "Postnational" is borrowed from Prime Minister Justin Trudeau, who was quoted in the New York Times in December 2015 as saying that Canada is the first "postnational State" (Lawson 2015). The second part of my title is plagiarized from what Nigerian-born playwright Inua Ellams told The Guardian in a 2017: "I became a black man when I arrived in England." The plagiarism is unintentional, because I came across the quotation after submitting the title "becoming Canadian" to the conference organizers.

Because of the venue, I've decided against a PowerPoint presentation. It seems rude to set up a screen in someone's house, namely, here in Ambassador Kati Csaba's residence. Deuxième chose : Je présenterai ma contribution en anglais, mais je dirai aussi quelques mots en français.

The title of this conference is delightfully captivating: "Postmodern Migrations: Canada / Les migrations postmodernes : Le Canada." The title is delightful because it contains two words that are guaranteed to polarize, perhaps to rile and anger.

"Immigration" should be a neutral, descriptive term - after all, humans have been moving from caves and homes and homelands for millennia; but the word has become dangerously politicized. The question "Are you for or against immigration?" has become a simplistic test of values. It is as if your one-word response reveals and sums up your entire worldview, politics, and degree of tolerance.

"Emigration", meanwhile, is a scary topic for where I now live because thousands of young, educated, and highly motivated Slovenians and other Central Europeans are leaving for the United Kingdom, Germany, Australia, the United States, and of course Canada.

But the conference title is not "immigrations" or "emigrations" but "migrations." That makes me happy because I have always mixed up the two words, even though I can rattle off that "one emigrates from a place; one immigrates to a place," and even though I have become an immigrant and emigrant (though a citizen only of Canada). I blame Canada for why I can't keep the im- and em- words straight. Canada is a place you come to: it is a land of immigrants. You emigrate to Canada and then you stay there. That's the story and history I grew up with. That one-way-ticketness is why the plural "migrations" also

1 This paper is a very slightly adapted version of a pre-dinner talk I gave at the Canadian Embassy Residence in Belgrade on 5 April 2019. I have deleted a few of the more topical references but have retained most of the asides (hence the many parentheses). 
feels strange to me. Canada is a goal, an end-point - you arrive in Canada and you root yourself there to make a new life.

The other contentious word in the conference title is "postmodern." The online Stanford Encyclopedia of Philosophy begins its entry on "Postmodernism" with a wisecrack: "That postmodernism is indefinable is a truism." No easy and agreed-upon definition exists. I admire the encyclopaedia's honesty, and though I will refer here and there to concepts thought to be "postmodern," I am not going to attempt to define the term.

I will, however, outline a few of the critiques of postmodernism because they will be hovering drone-like over my talk. I will spend the rest of my time, and yours, considering myself as a migrant in Central Europe and interweaving my own thoughts and experiences with quotations from Canadian authors Josip Novakovich, Nancy Huston, Mark Anthony Jarman, and Rohinton Mistry. The focal points of my talk are: choosing a country and choosing your story; the ol' English Canadian accent and identity; and becoming Canadian.

But first, postmodernism. Some proponents and all critics of postmodernism note that it entails: First: an utter distrust of objective truth ("truth is what my peers will let me get away with," Richard Rorty is said to have said - which sounds like a definition of a lie). The focus on rhetoric and story-telling apparently gives us licence to bring history and fiction closer together.

Second: a distrust of language as a medium. There is the legitimate belief that language can't recreate or reproduce the world - that a correspondence between reality and word is not possible. (Which is why dogs say "bow wow" in English, but "wav wav" auf Deutsch, "hau hau" v slovenšcini, and "av av" na srpskom.)

Third: relativism, in aesthetic, but also in moral terms. From the left, Marxist critic Terry Eagleton claims many postmodernists believe "Milton isn't better than Superwoman, just different" (1997: 96). From the right, Canadian academic, lecture-circuit star and Youtube-luminary Jordan Peterson scoffs that postmodernism "is driven by resentment about virtually anything that ha[s] to do with any merit of competence or aesthetic quality" (2017). Each of these views suggests that postmodernists have forgotten how to make critical aesthetic judgements.

A quick recap of these critiques, recast in more neutral language. Postmodernism is: 1) suspicious about objective truth; 2) aware that language has limitations (something I, a migrant working in a foreign language, realize on a daily basis); 3) aware of differing moral and aesthetic standards.

Three decades ago, in The Canadian Postmodern, Linda Hutcheon wrote that Canadians have a "split sense of identity, both regional and national" (1988: 4). We should not live under any illusions of ethnic, religious, regional, or temporal sameness (since we don't even share a time zone). Also, living on 
the margins but next to the United States gives us a wry and ironic perspective on power. Irony is often a good perspective to have. Irony is often indifferent, irresponsible, and disengaged, but it is also an ability to see simultaneous truths and viewpoints, an ability not to fall into black-and-white thinking.

Canadians are lucky because we have easy access to the United States, including its excesses (those endless political campaigns, some awfully low low culture). But we have our own excesses. I think of the anti-Americanism my high school history and English teachers drilled into me (many of them, by the way, were American "draft dodgers" during the Vietnam War), sometimes the cultural nationalism of the $1970 \mathrm{~s}$ - according to some, one should read only Canadian books.

I mentioned that "emigration" and the plural "migrations" are slippery words to me because Canada is traditionally the goal. Perhaps I am the victim of one of those mythologies or grand narratives so often derided by academics, but, as mentioned, my experience growing up was that Canada is a place you travel to and don't leave.

You don't leave Canada because it's a wonderful country, because there are many opportunities, and because as a Hungarian-Romanian once friend told me: "After I got to Pier 21, I said, 'I'm never getting on another goddamned boat in my life." He'd had more than enough of travelling. For most of the world, getting to Canada means a long, long journey. (Pier 21, as you probably know, is the terminal in Halifax that was the starting point for new arrivals to Canada who had just crossed the Atlantic.)

When I told a Mumbai-born university friend I was moving to Slovenia, she said, "You idiot! Everybody knows you go West; you don't go in the other direction." "Idiot" or not, my journey to foreign lands is not unique. The Canadian "diaspora" has been calculated at about 2.8 million, or about $7 \%$ of the population (Welsh 2011). I find this number depressing because it means that, well, I'm not special. There are 2.8 million Canadians living abroad... that's 800000 more than the population of Slovenia, my new place of residence, but not really my "home."

Home. Argentinian-Canadian author Alberto Manguel says, "Home is always an imaginary place," for even "if we stay, the place we call home changes" as a result of "the arrival of new cultures," "the shifts of political divisions and ethnic regroupings," globalization (2007: 106) - or simply the passing of time (a point to which I will return). Perhaps home is more of a feeling, somewhere between a tummy ache and a yearning for a beaver tail or a Nanaimo bar. Perhaps Manguel is right about home always being "imaginary." Still, if I were living in Canada, specifically in East York, Toronto, in the house in which I 
was born, home would have a reality and an everydayness that would make it far less wispy, less imaginary.

A few words on where I'm coming from - because where we come from colours our entire existence, our way of seeing the world. When I was growing up in Toronto, I could easily have found speakers of 15 languages within half an hour, just by walking the length of Torrens Avenue. In junior high, there was an insult: "That's Canadian..." This local slur meant something like "that sucks" or "that lacks vigour" or "I don't wanna do it..." (My inside sources tell me it meant something like "bez veze" in Serbian.) There was a tacit ethnicity requirement: if your parents had what was thought to be a non-Canadian accent, or if your skin was white, you could not use that insult (my grandmother came from Summerdale, Alabama - current population c. 800; major town highlight: an alligator farm - but that didn't cut it). I found this unfair because I wasn't allowed to moan "That's Canadian" when the teacher announced a math test.

When my classmates hit puberty and turned rebellious, each would imitate their parents' accents. A rite of passage, it seems, was to backtalk, to back-yell, in Greek-Canadian, Japanese-Canadian, or Chinese-Canadian English. I found it

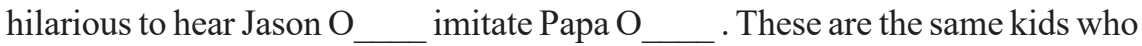
invented the vague "that's Canadian" insult. However, despite their invention of a local insult, they were not anti-Canadian.

I guess my classmates were in a sense postmodern, for one aspect of postmodernism that many Canadians will understand is that we can choose our identity - within certain limits. I can "identify as" many things, but not as a "Black man" or a "Cree"," and not even "a 'Bama man."

And I now move to the first literary quotation as I look at choosing identity, or at least a country.

\section{Choosing a Country and Choosing Your Story}

Josip Novakovich was born in 1956 in Daruvar, Socialist Federal Republic of Yugoslavia. He moved to the United States to study when he was twenty, and a few years ago he moved to Canada and acquired Canadian citizenship. He teaches creative writing at Concordia in Montreal. His most recent work, the short story collection Honey in the Carcase, contains this this wonderfully typical exchange: "You've got an accent. Where did you say you were from?" "I didn't say I was from anywhere" (2019: "Tumbleweed": 14). Anyone who has ever conversed in another language can identify with this question.

I'll spend a few minutes on the title piece of his 2012 essay collection Shopping for a Better Country. "Shopping" strongly echoes a wonderfully or woefully 
postmodern - as in, a consumerist - approach to identity. The shopping metaphor implies that we can purchase and put on nationalities like football jerseys, that we can acquire passports, and, presumably, reject them when they get too old and dusty - or, in the case of Novakovich, when we do not agree with the political landscape.

Advertisements and high postmodernist theory alike tell you that you can "create yourself," that you can and should take control of your life story. While this is true, we must also consider the audience or those who are labelling us - with or without our agreement - even as we're telling our story. In other words, our listener has to agree with what we have to say about ourselves.

Sometimes our audience wants to choose our story for us. For example, Novakovich mentions a publicist who pasted "on the cover" of his first book: "CCroatian-born writer-in-exile.' [...]. The word exile was supposed to be magnetic, to validate what I was saying, to lend the heft of suffering to my otherwise frequently satirical and silly writing" (2012: 6).

Elsewhere in "Shopping for a Better Country," Novakovich adopts the exile label. Sort of. "I am exiled from easy definitions, from clear identity," he writes, "Exiled from exile, but not from migration, emigration and immigration" (2012: 15). Thinking back to his university days at Yale, Novakovich recalls that Ivy League America wanted something different: "whenever my fellow students learned I was from Yugoslavia, they almost invariably asked me how I managed to escape. They expected me to be an exile" (2012: 3). He says his true story about "easy and legal departure in the role of a student" was both a "letdown" and boring, "so I came up with stories of swimming across the Drava River under gunfire" (2012: 3). In these lines, we can see that a conversational contract is in place - Novakovich is creating the story of his life, not least by serving up the wild sorts of tales his Cold War-era audience wanted to hear. This tell-and-be-listened-to relationship mirrors the give-and-take of identity formation. You create a story and others accept or reject it.

Self-creating, in fact, happens all the time, everywhere. Novakovich has said in interviews that a great advantage of living abroad is that you see the world around you as a stranger; you see the comic and the absurd, the different, and you reflect on where you're from and, by extension, you reflect on yourself, also as a divided self.

I've written in my abstract that "being Canadian outside Canada means I wrestle daily with a divided sense of self." "Every day I am reminded of my "Canadianness." Every day, I think, "Why can't Slovenians wait in line?" but also "Aren't they refreshingly direct?" In other words, I compare them to what I'm used to in Canada. 
With that, I'll move on to questions of identity: that bugbear that seems more important than ever. In the 1950s, thirty-seven books had "identity" in the title (thirty-five of them, I'm sure, by Canadians looking for the elusive "Canadian identity"). Now, thousands of "identity-volumes" are published each year (Coulmas 2019: 2), in every possible genre, covering topics from politics, to personal growth, to romance, to digital identity theft.

In his 2018 book, The Lies That Bind: Rethinking Identity, Ghanaian-British-now-American philosopher Kwame Anthony Appiah points out that identity matters more than ever, "because having an identity can give you a sense of how you fit into the social world" (9). Or, I might add, it gives you a sense of how you are fitted into the social world. Appiah's title is superb: lies are not true, but they can still serve a binding function, have a real-world effect.

\section{Accents?}

If we, as I've tried to show with the Novakovich example, are able shape our identities through the stories we tell about ourselves, language and accent are parts of our story. Novakovich, more or less from the start, could invent himself, however accented, in his new language.

I did not have this option. I spoke dismal Slovenian. My first apartment in Slovenia was in a smallish village of 5000. I'd go to the fishmonger and ask philosophically: "Kaj je riba?" or "What is fish?" The first time I went, the saleswoman showed a bit of frustration; the second time I went, she rolled her eyes when I entered (Not this clown again!). I have not suffered as a foreigner in Slovenia, but at times like this, I get a glimpse of the trials that newcomers to any country face. The third time, as I was purchasing some salmon, she said, "You're not from around here, are you?" My attempts to blend in through sly linguistic mimicry had failed.

Author Nancy Huston speaks of a similar linguistic wandering. Born in Calgary in 1953, she moved at the age of 15 to New Hampshire, and ended up in Paris after her BA studies. She has been short-listed for or won many prizes, among them the Governor General's Award, one of the Prix Goncourt ones, and in 2012 she took home the Literary Review's "Bad Sex in Fiction" award for her novel Infrared (originally published in French and translated by the author).

Her 1999 essay "Nord perdu" spoke to me very much. The expression "perdre le nord" means variously "to lose one's way" (i. e. to lose the compass point), maybe even "to lose one's wits" - a splendidly chosen title, since it blends geographical displacement with the sense of loss. Wisely, Huston opted for the title Losing North for her self-translation. In that long, autobiographical essay Huston writes, 'L'étranger ... imite. Il s'applique, s'améliore, apprend à 
maîtriser de mieux en mieux la langue d'adoption..." but the foreigner remains other, betrayed by "Une petite trace d'accent" or "un phrasé atypique" and the French are ready to pounce and categorize, to reduce the speaker from an individual to a generic Canadian (1999: 33).

So we can talk about postmodern self-creating through story-telling till the cows come home, but our language or accent constantly betrays us; we're slotted back into an old-fashioned categorizing world (where you could only mark one ethnicity on a census form).

Allow me to talk a bit more about accents, leaning on a passage from Mark Anthony Jarman's 2002 travel book Ireland's Eye: Travels. Best known as a short story writer, Jarman is not one for pat narrative closure. His tales are noisy, chaotic, full of references to popular music and high art and hockey, and imbued with a "crazy optimism" (Cumyn 2016) - crazy, because the protagonist usually has an unenviable lot in life: one is attacked by a cougar, another, the protagonist of "Burn Man on a Texas Porch," is permanently disfigured through a propane explosion. They are hurt into optimism or they learn to be optimistic in spite of everything.

Jarman was born in Edmonton, Alberta, to an English father and an Irish mother. He has stated that he feels more in tune with the Irish side of his lineage - like many Canadians, he is in a position to pick his heritage. In England, he has told me, he "always feels like a yokel" (a hick, a clodhopper) whenever he opens his mouth and produces the monotone buzz you're listening to at the moment.

Though non-fiction, Ireland's Eye is structured like a mystery as Jarman tries determine the facts around a grandfather's drowning. The mystery remains unsolved. In this passage, Jarman finds himself in a County Kerry pub. Another North American enters:

"Hey, you got anything like the Burgers and Beer place we got back home in Cleveland?" 1981, a loud voice in the pub in Dingle, the loud voice for dealing with foreigners. I go quiet [...]; I don't open my mouth for fear of my own stupid accent. The man looks at me, sensing something, hoping I'm American. I let him down. I keep my mouth shut, avert my eyes, pretend to be a Fenian hillsider from way back. (2002: 272)

This loud voice in the Irish pub is perhaps a caricature of the loud and loutish American tourist, but it's offset by Jarman's realization that his spoken English links him to the tourist because each has more or less the same "stupid accent"Jarman forces himself into silence, pretending to be an Irish rebel from the $19^{\text {th }}$ century and thus testing the boundaries of identity formation and engaging in a bit of time travel. It is as if Jarman fears losing control of his own story and, ironically, he falls into silence all because of his Canadian accent. 
I am not a phonetician, so I will turn to that great Canadian ear, to Mike Myers of Wayne's World and Shrek fame, specifically, from his 2016 book Canada. Before quoting Myers, let me point something out: my students are surprised that between Toronto and Vancouver - c. $4600 \mathrm{~km}$ - one hears no real change in accent (if you go the other way, Nova Scotia and Newfoundland, there is; in Quebec French there are more obvious local accents).

Myers' father was from Liverpool: "[He] made fun of my 'horrible' Canadian accent. At dinner, I would say, 'Hey, Dad, pass the sauce.' My father would wince [...] and would mimic me saying, 'Saaaass' in my accent, grotesquely exaggerating the flat A of the Canadian dialect" (2016: 36).

Myers accurately points out that "Canadians think the Canadian accent is, by its nature, the absence of an accent" (2016: 46). This is obviously false, and Myers calls it "deluded" (2016: 46), but the idea of a missing accent as a marker of identity is intriguing. As all Europeans know, accent or language is the marker of identity and belonging. (On a really good language day, I can baffle Slovenians into asking, "Which village are you from?!" My bizarre accent can't always be localized.)

Having an English-Canadian accent that sounds like many Americans' is existentially stultifying, limiting because - as you all know - the classic definition of what is a Canadian is "not an American." As some Europeans have told me, that is like a waiter explaining what is not on the lunch menu.

\section{Becoming Canadian}

And with that, I move on to the big question: How to become Canadian in this postmodern world. In 2009 the comedian Russell Peters performed a sketch called "How to Become a Canadian Citizen," which revolves around his dad's belief that you could do something magical to "Canadianize" yourself. Peters grew up in Brampton, a town of some 600000 just west of Toronto. His parents were born in India, and a caricature version of Peters Sr. is a mainstay of Russell's routines.

"How to Become a Canadian Citizen" is funny and wickedly clever. In the sketch, father Peters summons young Russell and proclaims, "Tonight we will become Canadians...," to which Russell replies, "Dad, I was already born here. I think I got it covered..." The father's plan is to have a barbecue for the neighbours: "We will invite all the neighbours; they will come over, eat our food and think we are Canadian" - to which, Peters says, "If you cook our food, they'll know we're not Canadian. Our food will have ... flavour..." 
To kill humour through a bit of theory: Peters does not adopt a "consistent" persona on stage - he's postmodern as he moves from "I was born here... I got it covered" to an elective affinity with Indian cuisine. He then plays the outsider, saying "sometimes Canadians, you know, white guys" don't like the entirely accurate joke about Canadian food being flavourless. This lack of a consistent persona was evident in the kids from my school saying, "that's Canadian..." before going home to accuse their parents of being foreigners.

The final author I'd like to look at is Rohinton Mistry, specifically, his 1987 story "Squatter." Rohinton Mistry was born in 1952 in Bombay, India, to a Parsi family (an English-speaking minority in India of about 200 000). He moved to Canada as an adult, after getting a BA in Mathematics and Economics. He worked for the Canadian Imperial Bank of Commerce, studied at night at the University of Toronto (majoring in English and Philosophy), and his wife encouraged him to quit and become a full-time writer. This he did, going on to receive a string of nominations and awards for his three novels: Such a Long Journey (1991); A Fine Balance (1995); Family Matters (2002). In addition to winning the Governor General's Literary Award, the Giller Prize, all three of his novels have been nominated for the Booker Prize.

Mistry's story "Squatter" deals with such weighty topics as immigration, minorities, and multiculturalism - all of these things are perilous to literature because they are abstract, and all of these are close to many pet topics of postmodernist theory: absence vs. presence, difference vs. sameness, the fluidities and border-crossings of the modern world.

Mistry comes at these weighty topics wisely in his literature: sideways and with a healthy dose of humour. Sarosh has decided to move to Canada and "was told by some [...] that his whole life would change for the better; others said he was making a mistake, emigration was all wrong, but if he wanted to be unhappy that was his business, they wished him well" (1987: 136). "My dear family, my dear friends," declaims Sarosh, "if I do not become completely Canadian in exactly ten years from the time I land there, then I will come back" (1987: 136).

There are strong echoes of the fairy tale: Sarosh has to carry out a difficult or impossible task within a given time period. The task is impossible because, as anyone remotely familiar with Canada knows, there's nothing specific you can do to become Canadian. Some have argued that's the downside of multiculturalism and diversity.

One speaker in "Squatter," in Bombay, pontificates about multiculturalism: "The Multicultural Department is a Canadian invention. It is supposed to ensure that ethnic cultures are able to flourish, so that Canadian society will consist of a mosaic of cultures - that's their favourite word, mosaic - instead of one uniform mix, like the American melting pot" (1987: 141). (This prose would 
be tedious to read at length because it sounds like it's from a citizenship manual.) The raconteur continues: "If you ask me, mosaic and melting pot are both nonsense, and ethnic is a polite way of saying bloody foreigner" (1987: 141). My students often take this passage to be a critique against multiculturalism and tolerance - even though the phrase "if you ask me..." is a clear hint not to accept the comments as gospel.

I can understand students' desire to take this line about "bloody foreigner" as a sort of motto. After all, Canada is a complex country, and though we can say, every nation is a construct, every nation is an invention or an imagined community, Canada is really complex: John Ralston Saul writes that Canada's very "strength $[. .$.$] is its complexity; its refusal of the conforming, monolithic$ nineteenth-century nation-state model" (1997: 81).

So how does one become Canadian? Sarosh thinks you have to sit down on a toilet rather than squat over a hole in the floor as he is used to doing. In other words, in order to become "completely Canadian" (1987: 136), he has taken it upon himself not to be a "squatter" but to be one who defecates by sitting regally on the throne.

The climax of Sarosh's story - which is embedded within a series of stories in "Squatter" - occurs when his self-imposed ten years are almost up. His airplane headed back to Bombay is taxying on the runway when suddenly, unfortunately, Sarosh needs to use the facilities. Apparently it's hard to perch on a toilet in a moving plane. So Sarosh sits as he performs his business. Mistry parallels the movement of the plane with the movement of Sarosh's bowels: "The plane moved faster and faster. And Sarosh pushed hard, harder than he had ever pushed before, harder than in all his ten years of trying in the new land" (1987: 146). Mistry mischievously tweaks the cliché of making it in the New World through gumption and effort. Push harder and you will produce the result you desire.

And Sarosh does succeed. He bursts out of the toilet, proud and delighted that he can now - in line with his own absurd challenge - stay in Canada, and declares, in a fine pun: "'You don't understand! [...] I must get off the plane! Everything is all right, I don't have to go any more..."” (1987: 146).

Mistry's "Squatter" works so effectively and is fun to teach because the task Sarosh sets himself is arbitrary and because the story as a whole does not allow for simple readings. This is not an allegory but a story about one man's perceived failure to become Canadian. It is also about the impossibility of returning comfortably to Bombay. When Sarosh returns to his small Parsi community in India, he finds himself "desperately searching for his old place in the pattern of life he had vacated ten years ago" (1987: 148). 
"Desperately searching for his old place in the pattern of life..." is a phrase that speaks to me and that I think of almost every time I return to Canada for a visit. Earlier, I disagreed with Alberto Manguel, who argues, "Home is always an imaginary place" (2007: 106). But whenever I return to the Torrens Avenue of my childhood, I am inclined to agree with him. For the Canada I left does not exist anymore - the penny or one-cent coin is no longer in circulation; for me, the cell phone is a Slovenian invention because when I left Canada they weren't ubiquitous; even language is slipping away: my sister once laughed mercilessly at me when I said I'd purchased a "mobile" rather than a "cell."

\section{Strange Spaces between...}

As I move to the final few minutes of this talk, let me quote Andrew Holman, another Canadian Canadianist working outside Canada: those of us who have left "inhabit strange spaces between our here homes and our homes of old - those places where our siblings still live and childhood friends retire, where parents move house, age too quickly and then pass away. The places that are different every time we return, and not ours anymore" (2017: 3).

Perhaps I have become an ex-Canadian, a not-so-slick cosmopolitan, most at home in the no-place of the train station café. Indeed, though occasionally I hear, "Zdaj si pravi Slovenec" (now you're a real Slovenian), I am surprised that nobody has told me, anywhere, "you're no longer Canadian."

And yet... in my head I am constantly whisked back to Canada, for example, while listening to the BBC's Desert Island Discs, a show where the prominent guests pick "Eight tracks, a book and a luxury" that they would take if they were shipped off to a desert island. A few weeks ago, I heard Margaret Atwood discuss Leaside High School, a school she and I attended. I laughed as she explained our school's absurd Gaelic motto ("Seas Gu Dileas" - Stand Faithfully), and as she described our school's modern but totally impractical architecture. Was she speaking directly to me in Slovenia, as I headed to Lidl, the German-owned supermarket, listening through my Dutch Phillips headphones on my made-inChina Korean Samsung Galaxy phone? Is this not a snapshot of globalization? Of placelessness, regardless of where you're located? Or crass consumerism globally governed by multinationals?

"As the $21^{\text {st }}$ century wears on," writes Manfred B. Steger, "people around the world will [realize] that they live in a transitional era moving from the modern nation-state system to postmodern forms of global governance" (2017: 79). These words partly echo what Justin Trudeau told The New York Times in late 2015 - that Canada is "the first postnational state" (Lawson 2015). "An ambitious policy statement," noted one critic (Coulmas 2019: 60). "Too radical" a thought 
to admit in Europe, lamented one European politician. Trudeau's statement is a fact of (postmodern?) Canadian life and the line followed a convincing justification: "There is no core identity, no mainstream in Canada" (Lawson 2015) - which is why you can be a good Canadian yet not own a barbecue. Does this mean a lack of any sort of essence? That, like the Canadian accent, the Canadian identity is an absence of an identity?

I don't know, but I don't think so. I would, however, like to end with two words from fellow Torontonian Margaret MacMillan - the Oxford-based historian who also had her turn on Desert Island Discs. She says that coming from Canada helps her observe history with a certain amount of detachment, because the country is "small in terms of power and population" (2019).

Just after selecting a song called "Un Canadien errant," she and host Lauren Laverne speak about the world of today - the postnational, postmodern world that nevertheless believes in nationalism; they speak of polarization, where politicians and voters of different parties won't even talk to each other, where we've seen the aimless "drift" of MacMillan's now-home Great Britain, where we've seen the rise of "authoritarian leaders," and where we've seen an increasing isolationism, where wall-building and barbed-wire are evident, even within the European Union.

"Where are the bright spots?" asks the host.

I loved MacMillan's answer. No waffling, no fancy-footworking about "what is truth?", no relativising, and no equivocating. Her words were very un-postmodern and very optimistic: "Well, Canada." And on that positive note, I conclude. Thank you.

\section{WORKS CITED}

Adams, Michael. Could It Happen Here? Canada in the Age of Trump and Brexit. Toronto: Simon \& Shuster, 2017. eBook.

Appiah, Kwame Anthony. The Lies That Bind: Rethinking Identity. New York and London: Liveright, 2018. Kindle.

Coulmas, Florian. Identity: A Very Short Introduction. Oxford: Oxford University Press, 2019. Kindle.

Cumyn, Richard. “19 Knives: Mark Anthony Jarman.” Literary Review of Canada. 16 March 2016. Online: https://reviewcanada.ca/the-lrc-25/19-knives-markanthony-jarman/. [accessed 17 September 2020]

Desert Island Discs. "Margaret Atwood.” Aired 13 April 2003 on BBC 4. https:// www.bbc.co.uk/programmes/p0093713. [accessed 17 September 2020] 
------. "Margaret MacMillan.” Aired 24 February 2019 on BBC 4. https://www. bbc.co.uk/programmes/m0002rm7. [accessed 17 September 2020]

Eagleton, Terry. The Illusions of Postmodernism. Oxford: Blackwell, 1997.

Ellams, Inua. "'I became a black man when I arrived in England': Inua Ellams on his play Barber Shop Chronicles." (video). Interview by Iman Amrani. The Guardian. 12 December 2017. Online: https://www.theguardian.com/stage/ video/2017/dec/12/i-became-a-black-man-when-i-arrived-in-england-inuaellams-on-his-play-barber-shop-chronicles. [accessed 17 September 2020]

Holman, Andrew C. "Editor's Notebook." Bridgewater Review, 36.2 (November 2017), 2-3. Online: https://vc.bridgew.edu/cgi/viewcontent.cgi?article $=1984 \&$ context $=$ br_rev. [accessed 17 September 2020]

Huston, Nancy. Nord perdu : suivi de Douze France. Arles and Montreal: Actes Sud/Leméac, 1999.

Hutcheon, Linda. The Canadian Postmodern: A Study of Contemporary English-Canadian Fiction. Toronto: Oxford University Press, 1988.

Jarman, Mark Anthony. Ireland's Eye: Travels. Toronto: Anansi, 2002.

Lawson, Guy. “Trudeau's Canada, Again.” New York Times, 8 December 2015. Online: https://www.nytimes.com/2015/12/13/magazine/trudeaus-canada-again.html. [accessed 17 September 2020]

Manguel, Alberto. The City of Words. Toronto: Anansi, 2007. eBook.

Mistry, Rohinton. "Squatter." In Tales from Firozsha Baag, 127-149. Toronto: Penguin Books Canada, 1987. eBook.

Myers, Mike. Canada. Toronto: Penguin, 2016. eBook.

Novakovich, Josip. "Shopping for a Better Country." In Shopping for a Better Country, 1-15. Westland, MI: Dzanc Books, 2012. Kindle.

-------. "Tumbleweed.” In Honey in the Carcase, 13-24. Ann Arbor, MI: Dzanc Books, 2019.

"Where are your clogs? You'll catch a cold!" Interview with Jason Blake. The Central European Journal of Canadian Studies / Revue d'Etudes Canadiennes en Europe Centrale, 14.1 (2019), 5-9. Online: https://digilib.phil. muni.cz/bitstream/handle/11222.digilib/142440/2_CentralEuropeanJournalCanadian_14-2019-1_3.pdf?sequence=1 [accessed 17 September 2020]

Peters, Russell. "How to Become a Canadian Citizen." YouTube, uploaded by UnPatched, 8 April 2009. https://www.youtube.com/watch?v=QaF05LuGqxs. [accessed 17 September 2020]

Peterson, Jordan. "Modern Times Camille Paglia and Jordan B. Peterson." Interview with Camille Paglia. 19 October 2017. Online: https://www.youtube. 
com/watch?v=v-hIVnmUdXM\&list=LLl_4wzX7nAg_RioyTba5jcQ\&in$\operatorname{dex}=315$. [accessed 17 September 2020]

Saul, John Ralston. Reflections of a Siamese Twin: Canada at the End of the Twentieth Century. Toronto: Viking, 1997.

Steger, Manfred B. Globalization: A Very Short Introduction. Oxford: Oxford University Press, 2017 (2003). eBook.

Welsh, Jennifer. “Our Overlooked Diaspora: Canada's millions of citizens abroad could be a national treasure - given the right strategy." Literary Review of Canada. March 2011. Online: https://reviewcanada.ca/magazine/2011/03/ our-overlooked-diaspora/. [accessed 17 September 2020] 